\title{
Freudian Psychoanalysis and the African Folktale
}

\author{
Prof. Njogu Waita* \\ Department of Humanities, Chuka University, P.O. Box 109 Chuka-Kenya
}

*Corresponding Author: Prof. Njogu Waita, Department of Humanities, Chuka University, P.O. Box 109 Chuka-Kenya

\begin{abstract}
This paper is application of Freudian Psychoanalysis on four African folktales recorded from Central Kenya. The folktales were audio-recorded from live performances, transcribed from the original Kikuyu language and then translated into English. Specifically, the paper seeks to understand the role of the folktales in human psycho-social development with the assumption that symbolic and structural constitution of the folktales have a bearing on the psycho-sexual maturation of individuals in African societies. This study uses psychoanalytical criticism as the theoretical and methodological framework of analysis. The findings in this study indicate that folktales play a significant role in a people's psycho-social and psycho-sexual development. The unconscious drives of the 'id' are fulfilled in the conscious expression of imagery and symbolism in the folktales helping in the consolidation of the ego and the superego in individuals.
\end{abstract}

Keywords: African, Folktales, Freud, Psychoanalysis

\section{INTRODUCTION}

Psychoanalysis has been a major component of literary and cultural criticism over the years. The birth of theoretical and practical psychoanalysis is associated with Sigmund Freud (1856-1939), who worked as a doctor in Vienna, Austria, in the late nineteenth and early twentieth Centuries. Following Freud, we have come to accept the idea of, the 'unconscious,' That, when we lead normal lives, certain images and ideas are constantly suppressed from normal consciousness. That way we behave like normal people. However, there are instances when these ideas and images break loose. For instance when we are asleep (dreaming) or mentally ill. This gives full live to the wishes we are ashamed of. Freud posited that when the restrained images are set loose, we are engaged in an act of 'wish fulfilment' (Freud: 1900, Hall 2001:103-104).

Freud further argued that the wishes being fulfilled in the unconscious were uniformly of a sexual character. He divide human personality into three interrelated parts; the 'id', the 'ego' and 'superego.' Freud further outline five stages of human development to include; the oral, anal, phallic, latency and genital stages. He concluded that sexual desire has its origins early in the infancy and is key in understanding of human psychology. (Freud: 1905, 1915, Badcock: 1992).

Freud never developed any systematic methodology in psychoanalytical literary criticism. In his study of dreams, Freud concluded they are a form of 'wish fulfilment' and suggested that dreaming is a process similar to the creation of fantasy and other forms of fiction. In his analysis the Greek story of King Oedipus, he was convinced that this story has appealed to us in time and space because it strikes a fundamental psychic cord. King Oedipus who killed his father and married his mother is nothing less than a childhood fantasy in which boys wish to get rid of their fathers in competition over their mothers love. Freud referred to the situation as the 'Oedipus Complex' (Freud 1910, Humberto 2012 (1969) 44-67).

Freudians have over the years subjected literature to psychoanalysis. By applying psychoanalysis to literary criticism it has been possible to interpret many aspects of modern culture that appear discordant and fragmented. (Davies: 1994:371).

The folktale in Africa is a veritable tool for transmitting a people's cultural heritage. The genre is a key tool for socialization and the psychological development especially for children. This is because the tale is able to hold the child's attention. It is entertaining and arouses the child's curiosity. At the same time the folktale also stimulates the child's imagination helping them to develop their intellect 
and to clarify their emotions (Bettelheim: 1995:5).The tale offers many answers to questions that baffle children and in the fantasy of the tale the child learns why things are as they are. Although the answers may be fictional they satisfy the children because as Tucker notes, 'the child's world is subjectively constructed around what ought to be true but not what is' (Tucker 1981:78). It is against this background we present the discussion on the application of Freudian psychoanalysis to the African Folktale.

\section{Psychoanalysis AND The African FolkTAle}

In this section, we shall apply Freudian psychoanalysis to African folktales. We shall seek to understand how the narratives are instruments of psychco-social development and how they consolidate the psychological maturity in the unconscious. We shall further seek to understand through the analysis how the unconscious drives of the 'id' find expression in the symbolism and imagery of the folktales. Our analysis will include four folktales titled; Father's Gourd, Wacici and Wamweru, Nyaga and Muthoni.

\subsection{Father's Gourd (Kanya Ka Baba)}

This is a common traditional folktale in Kenya. It is a story about two daughters and their father's gourd. Though identical, the two daughters are disparate. One is obedient and consistent, the other is disobedient and headstrong.

The story sets off with the obedient daughter being sent to the river to fetch water. She picks her 'father's gourds' as the container to fetch the water with. Traditionally this was a gourd reserved for the exclusive use by the father as the head of the family. It is used to preserve and serve fermented milk for the father. As the obedient girl is drawing water, the gourd accidentally slipped and is swept downstream. Shocked at the loss of her father's prized gourd, the girl follows it downstream, singing for it, urging the gourd to stop, to wait for her so that she can retrieve it.

As the story unfolds this turns out to be a long journey through a variety of fantastic landscape. Along the way, the girl encounters different kinds of animated foodstuff. The foodstuff consists of delicacies that beseech the girl to feed on them because as they say 'they have nobody to eat them'. Sweet potatoes are digging themselves out of the ground, cooking themselves up and eating themselves. Likewise sugar canes are cutting themselves up, peeling themselves and eating themselves. The delicate meat is roasting itself up, cutting itself into pieces and eating itself up. In turns, the foods entreat her to eat them, but she refuses. Her retort to each one of them is that she 'does not eat food that consumes itself'.

The day wears out as she follows her father's gourd. It gets dark and the girls seek accommodation from a house she comes by. In that house is an elderly woman and her daughter almost an age mate of the Obedient Girl. She is welcomed into the house. The mother cuts a lamb's tail into small pieces, fries it and offers it to the two girls. Though very hungry, the obedient Girl behaves with decorum allowing her mate to have her share of the delicacy. After the meal they go to sleep. The following morning the woman asks the girl what her mission was. As she recounts the story about her father's gourd the woman produces the gourd and hands it over to the girl. She also offers her visitor a present. But she has to choose form two pots; one that is new and another that is old and used. The girls choose the latter and out of it she retrieves beautiful ornaments for her ears, neck and feet. The old woman fills the gourd with a liquid and tells the girl to take it to her father. She is however warned not opened the gourd on the way. When she takes the gourd back her father the liquid turns out to be pure honey. The father is very happy and blesses her.

The Obedient Daughter's ornaments becomes a source of conflict between her and her sister. The sister would like to borrow them. But the other sister refuses to lend out her ornaments. She tells her how she acquired them when her father's gourd slipped and was carried downstream. The Disobedient daughter picks her father's gourd rushes to the river, deliberately throws it in and follows the gourd downstream

The same journey is re-enacted but the second girl's reactions are the opposite of the first one. She eats all the foodstuff that request her to do so. When she gets to the old woman's house and is served with the fried pieces of lamb's tail she eats everything without sharing with the host child. In the morning she is given the choice of the two pots. She chooses the new pot. Out of it she pulls an ugly 
bark clothe. She is then handed over her father's gourd with the same interdiction not to open it on her way home. On her way home she opens the gourd's cork, and out it spews abominations contracting her with leprosy. On arrival home she is condemned to live the rest of her life as an outcast.

This tale offers several psychoanalytical interpretative dimensions. Firstly the story delves into the Freudian principle of pleasure verses reality. This principle delineates the conflicting of the pleasure drives of the id that seek immediate gratification and those of the ego that represent the ability to defer gratification. (Freud:1920,1923, 10; Kendra: 2016). The story represents the process in satisfying the desires of the id in an acceptable manner through the control by a well-developed ego which allows the obedient girl to be able to control her impulses and delay gratification. In the story she is able to follow the reality principle, is rational and able to make controlled choices. She has the ability to assess the reality of the external world and act accordingly other than for the sake of immediate gratification. In the end the drives of her id are met when she is finally rewarded with beautiful ornaments by the elderly mother and the honour from her father

This key psychological lesson in the story can only be learnt through the binary of the obedient daughter.

The duality of existence and the contradiction of the pleasure versus reality principles is explicated in the action of the sister, the disobedient daughter. She follows the pleasure principle and seeks immediate gratification and ends up in ruin. The story then dissects the dangers of the drives of the id. The second daughter follows the desires of her id and she ends up in self-destruction and social punishment. The story demonstrates that without the maturity of the ego, the individual stands in danger. For the adolescent, the delicacies that tempt the young girls to eat them, are anti-social allencompassing unconscious desires which if acted upon will lead to destruction. But by persevering and being consistent one can overcome all these temptations through the strength of their ego.

The psychological value of this tale transverses the two principles. It explores the duality of existence that cannot be wished away. This is especially significant for the young and adolescents. The pleasure principle which is followed by the second daughter is a trait we recognize in ourselves. The negative image in the second daughter becomes an eternalization; the defense mechanism against the pain and guilt of treading the path of the pleasure principle.

The moral polarization in this tale serves a significant empathetic function. The audience can identify with the characters who arouses the greatest sympathy. The process of identification becomes both a moralizing as well as a psychoanalytic function. The roles of the two characters can be cast and recast to apply appropriately to affirm the self or assign the evil and negative role to the sibling. This way the tale helps the young to deal with sibling rivalry unconsciously without resorting to open confrontation. By casting the sibling sister rival as the disobedient daughter, sisters can cultivate a heathy relationship between themselves. We shall see the application of this psychological 'displacement' of 'projection; applied further in the narrative of 'Wacici and Wamweru', analysed below.

\subsection{Wacici and Wamweru}

This is a story about two half-sisters, Wacici and Wamweru. Wacici's mother is dead and she is left under the care of Wamweru's mother. The two girls are close friends and do everything together. But Wacici is more beautiful than Wamweru. She attracts more suitors than her half-sister which makes her step-mother jealous. She decides to kill the step daughter so that her own daughter is left without competition. One day she makes sure she is alone in the woods with Wacici and buries her in a burrow and leaves her for dead. But Wacici survives in the burrow for a number of days feeding on soil and her clothes. One day, while grazing goats in the wood, her brother notices a strange behaviour from one of the he-goats. It remains on the same spot on a mound of soil bleating. Upon investigation, he hears Wacici's faint voice calling for help from beneath. He fetches his father and together they rescue the girl from the burrow alive. She is taken back home and nursed back to health. Her father punishes the step mother by burying her in the same burrow she had consigned Wacici.

Psychoanalytically, we can interpret this story in at least two dimensions. Firstly within the notion of 'feminine Oedipus complex' or 'Electra complex' in which there is a conflict between the daughter and mother for the possession of a father's love (Freud: 1905, Jung; 1913). The mother wishes to do stop this competition by doing away with the daughter. The story does not allow the mother's plot to 
succeed but indeed ends with her own punishment. In the unconscious realm the story condemns and prevents the habouring and acting on such feelings by the mother. On the other hand, the story provides a perfect cathartic wish fulfilment for the daughter who harbours conscious or unconscious feelings of rivalry with the mother over her father's love.

The tale then becomes the instrument psychological balance that cultivates an enduring relationship between mother and daughter.

At the other level, the psychological defense mechanism act of 'displacement' or 'projection' discussed earlier is also at play in this tale. The step-mother in the story represents any mother of a child. The mother is normally the all-giving protector of the child as they pass through the maturation stages. But contrary to the wish of the child, the mother cannot be available all the times. This leads to experiences of pain and resentment by the child. The experience of a mother as bad can lead to a situation of psychological imbalance.

However, internalising this story over repeated performances offers the child a psychedelic perception of the mother. The child can split her mother into two; the good mother who is dead and the evil cruel step mother. The child's feelings of guilt and anger against her mother can then be thrust into the fantasy of the evil step mother. That way the child is not devastated by experiencing her mother as bad and a healthy relationship between the two is maintained. The tale then becomes significant in delineating inner experience and personal development. Through the symbols and images the tale provides essential steps of maturation to independence (Bettelheim: 1975:70).

\subsection{Nyaga and Njengei}

The story of Nyaga and Njengei presents interesting insights into the Freudian concept 'Oedipus conflict' and 'sibling rivalry'. (Freud: 1900, Herskovits \& Herskovits 1958). This story demonstrates how such conflicts can lead to the destruction and total annihilation of the family. The main character in the story live in a polygamous household. The initial conflict in the story is a prolonged drought that has caused a famine in the society. In order to survive the family depends on hunting game and gathering wild vegetables along river banks. The men go out hunting while the women forage for the vegetables.

One day, Nyaga, his half-brother Ngari and his father go out to hunt. They corner and trap an animal, known as Njengei atop a tree. The animal pleads with Nyaga to be released, promising that one day she, (that animal) would assist him. Nyaga feels pity on Njengei and releases her against his father's order to hold on the trapped animal. Ngari notices the on goings, but does not say anything at the moment. Back home in the evening, when they are being served the miserly vegetables, Ngari threatens to reveal what transpired to the father. To appease him, Nyaga offers a portion of his meal to Ngari to maintain his silence. Henceforth, the blackmail continues during every meal time until the mother notices Nyaga was wasting. She closely supervises the mealtime giving Ngari no chance to get his black mail portion. In revenge, Ngari reports the Njengei incident to the father. The father's reaction is drastic. He deceptively takes the boy back to the place where he released Njengei and crucifies him on the same tree.

The Njengei happens to pass by the same tree and releases Nyaga. Njengei also offers to become Nyaga's benefactor bestowing upon him unlimited wealth. The wealth in the form of livestock is given to Nyaga on condition that nobody should ever slaughter Njengei for food except Nyaga and that will be only when the Njengei is very old and turns blind.

As the story unfolds, Nyaga's sisters, when foraging for vegetables in the valleys, inadvertently discover he is still alive. They inform their mother who goes to the valley and confirms that indeed Nyaga is alive. Nyaga invites them to his abode across the valley so they can escape from the famine ravaging the household. On the appointed day they come, but to cross over, they have to do so in a single file over an improvised rope bridge manned by Nyaga. The father is the last to cross. When the old man is halfway across, Nyaga lets go the ropes and his father drops and perished in the river below.

The rest of the family join his homestead, where there is plenty to feed on. He informs them that they can enjoy anything there but warns them never to touch his benefactor. But his brother Ngari longs for the taste of roasted Njengei meat. And one day while Nyaga is out grazing his livestock, he slaughters 
the animals and puts the meat on fire to roast. This leads to an ultimate showdown. Nyaga catches the scent of his roasting benefactor. He hurries home and in extreme anger and sadness, that his benefactor has been slaughter, he systematically kills everything and everyone on his compound.

Using his extremely sharp sword, He puts down his livestock including his favourite bull, then kills all his relatives and finally turns the sword on himself and dies.

This folktale demonstrates the pitfall that may occur if there is failure to successfully negotiate the Oedipus complex during the Freudian 'phallic stage' of psychosexual development. In the throes of Oedipus complex, Nyaga resents his father for standing on his way into his mother's love. In this story, the boy child's wish to destroy his father is actualized. The boy's resentment of his father is expressed in his disobedience and his action that plunges his father to his death. The unconscious desire of the 'id' are overriding in this story. They overcome the reasoning of the 'ego'.

The Oedipus conflict in this story is compounded by the problem of sibling rivalry. Ngari is jealous of his brother and from the incidents of the story he does engage in the wish or fantasy that, he can, one day destroy his brother. This wish is manifested in the blackmail on his brother and in slaughtering his benefactor against his brother's interdiction. In the context of Freudian psychoanalysis, this story indicates that, if the unconscious desires are not properly navigated they can lead to impossible situations. Competition between parents and children can only lead to misery and if these desires are allowed to flourish, they can result to traumatic situations, violence and tragedy.

Significantly, this story offers children, as they grow up, the opportunity to reenact their unconscious desires in the fantasy of tale and consequently aid them overcome the conflicts, develop their superego and achieve psychological maturity. Out of the process of this conflict arises the realization that the rivalry between children and their parents and between siblings, must be balanced by the opposite forces of loving and longing (Bettelheim: 1975:12; Kofman: 1991:35).

\subsection{Muthoni}

The Story of 'Muthoni and her Mother's Wound' is a common folktale in Kenya. It offers startling psychoanalytical insights into Electra complex, female sexual maturation and gender power relations in traditional African societies. On the surface, this is a simple straight forward story. Muthoni's mother is inflicted with a wound that does not respond to medication. When Muthoni's father and brothers seek alternative medication from the medicine men, they are always advised that the wound can only be healed by the leaves from a leaves atop the Munyenyia tree. The tree is found in only one place; the homestead of the chief ogre, Mangeca. They are afraid of going there and hence keep moving from one medicine man to another but they get the same advice.

One day, as they proceed to yet another medicine man, Muthoni discreetly follows them. She eavesdrops on their consultations with medicine man and discovers the truth. When they get back home, she volunteers to go and fetch the leaves despite the high risks of the venture. She crosses over into the ogre territory, outwits the ogres, procures the leaves and manages to escape back home into human territory. The leaves are prepared and applied to the mother's wound. The wound heals and the family is able to once again lead a normal life.

From the outset, this story poses feminist, gender and psychoanalytical concerns. An analysis of this tale discounts the notion that Freudian epistemology is phallocentric and does not account for the feminine. That the male is presented as the only bearer of knowledge with the ability to penetrate both women and texts. The narrative further discredits assertions that Freudian criticism fails to recognize gender power relations in patriarchal contexts. (Moi:1981). The tale demonstrates that Freudian criticism can explicate feminist and gender dimensions in the African folktale making it a veritable tool for understanding female psycho-sexual development.

The initial conflict in the story of Muthoni is her mother's wound which does not heal. In the symbolic world of the tale, the wound represents a woman who has been unable to reach menopause despite being advanced in years.

Muthoni's mother yearns to remain young and fears 'the rejection of the post menopause woman' (Joanna: 1996: 86). But in the process she blocks he daughter's path to sexual awakening, sexual maturity and realization of her womanhood. 
Muthoni must transcend the block created by the wound and bring the healing leaves. Her father and brothers, who represent one aspect of male hegemony in the story cannot assist her. Hence they lie after every visit to the medicine men. They do not wish for the wound heal because they fear this may lead to the development a post-menopausal 'phallic woman' who eventually usurps male power. (Arikan 2018, Laznik: 2014, Brooks 2006).It is only the daughter then, who can empower her mother and in the process resolve her own 'Electra complex'.

Muthoni accepts the challenge to go and fetch the healing leaves. In the process she accepts the challenge of maturation into womanhood. But the struggle for successful self-realization is also a struggle against the male world. Before she can bring in the healing leaves, she must first overcome the fear that is in her father and brothers. She must also be able to overcome the ogres from whose abode the leaves are located. The ogres symbolize the threat of male sexuality in Muthoni's world. The healing leaves to be procured are at the top of the tree in the middle of the ogre's homestead. By procuring them, Muthoni symbolically overcomes the unconscious desire for phallic extensions. She is enabled to overcome the oedipal feelings for her father and the threat of being devoured by male sexuality. The leaves heal the delayed menopause of her mother enabling Muthoni to realize her womanhood. In the structural pattern and the content of the tale, Muthoni is able to achieve this.

\section{CONCLUSION}

This study demonstrate Freudian Psychoanalysis is significant in the analyses of the African Folktale. The discussion above indicate that the folktales are key instruments of psychological maturation. They play an important role on teaching and conditioning on acceptable behavior patterns in the society. The folktales in the study emerge as critical tools that assist the young to successfully wade through the various stages of psycho-sexual development into psychological maturation. Beneath the surface of the African folktale lies deeper psychological function critical to the socialization of young people.

The folktales addresses and analyses psychological challenges in the various stages of psycho-social development of individuals and do so an optimistic way without giving to defeat. More than any other media, the tales present the opposing binaries of the world; life and death, good and evil, peace and war, heroism and cowardice. The tales inculcate into the young, that the struggles against difficulties is unavoidable and that if one does not shy away from these problems they will emerge victorious. (Lewis: 1966:36)

Literary texts are also structured in such a way that the audiences are participants and spectators at the same time. By participating in the story, individuals can reflect on their inner world and act out fantasies and wishes that resolve their many psychological conflicts. The form and structure of the tale then, are particularly suited to meet these psychological needs. This is apparent in the way the tale is ordered always starting with conflicts, interdictions, action, punishment, rewards and happy or unhappy endings. The structure of the tale suggest images and patterns that the audience can use to structure their own dreams and wishes offering them the possibility to externalize their fears, desires and inner conflicts and eventually emerge as more secure persons. (Lesser: 1977:169-170).

\section{REFERENCES}

[1] Appleyard, J.A.S.T. (1990). Becoming a Reader. Cambridge, Cambridge University Press.

[2] ArikanSeda(2018). The Phallic and Vulvic Mothers of JeanetteWinterson: Oranges are not the only Fruit and Sexing the Cherry in ZfWT Vol.10. (1) 2018: 75 - 93.

[3] Badcock, Christopher (1992). Essentials of Freud. Oxford, Blackwell.

[4] Bettelheim, Bruno(1967). The Empty fortress. New York, Free Press.

[5] _ (1975). The Uses of Enchantment. New York. Penguin.

[6] Brooks Carellin (2006). Every Inch A Woman: Phallic Possessions, Feminists and Text. Vancouver, UBC Press.

[7] Cherry, Kendra (2018). Theory of Personality Psychology: delayed Gratification and Impulse Control. www.verywellmind.com

[8] Freud, Sigmund. (1900). The Interpretation of Dreams inJ. Strachey et al. (Trans.) (1976).The Standard Edition of the Complete Works of Sigmund Freud, New York, Norton and Company (Vol IX \& V).

[9] (1905).Three Essays on Sexuality in Strachey et al. (Trans.) (1976).The Standard Edition of the Complete Works of Sigmund Freud, New York, Norton and Company (Vol VII). 
[10] _ (1910). A Special Type of Choice Made by Men (Contributions to the Psychology OfLove1) in Strachey et al. (Trans.) (1976).The Standard Edition of the Complete Works of Sigmund Freud, New York, Norton and Company (Vol. XI) (1920). Beyond the Pleasure Principle, In J. Strachey et al. (Trans.) (1976) The Standard Edition of the Complete Psychological Works of Sigmund Freud, Vol.(XIX.)

[12] _ (1923). The Ego and the Id. In J. Strachey et al. (Trans.) (1976)The Standard Edition of The Complete Psychological Works of Sigmund Freud, (Vol. XX).

[13] Gumn Daniel (1988). Psychoanalysis and Fiction. Cambridge. Cambridge University Press

[14] Hall, Donald E. (2001). Literary and Cultural Theory. Boston, Houghton Miffin.

[15] Herskovits F.\& Herskovits M. (1958). 'Sibling Rivalry, The Oedipus Complex, and Myth'. In Journal of American Folklore, Vol. 71. (279), Jan-Marc. 1-15

[16] Holland, Norman (1975). 5 Readers Reading. New Haven, Yale University Press

[17] Humberto Nagera. (Ed.). (2012 (1969). 'Oedipus Complex' in Basic Psychoanalytic concepts on Libido. London. H. Karnac Books P. 64-67

[18] Jung, Carl Justav (1915). 'The Theory of Psychoanalysis and Neurosis' in The Journal of Nervous and Mental Diseases Publishing Company. Issue No. 19.

[19] Joanna, Frueh(1996). Erotic Faculties. Berkeley, California University Press

[20] Kofman, Sarah(1991). Freud and Fiction. Oxford, Blackwell

[21] Laznik, Marie Christine (2014). 'Female Sexuality and Menopause'. Https/www. Laznik.fr

[22] Lesser, Simon. (1962). Fiction and the Unconscious. New York, Vintage Books

[23] Lewis C.S. (1966). Of Other World. Essays and Stories. London. Geoffrey Bles

[24] Moi, Toril. (1981) 'Representations of Patriarchy: Sexuality and Epistemology in Freud's Dora' in Feminist Review. 9 - 60 - 71

[25] Tucker Nicholas (1981). The Children and the Book. Cambridge. Cambridge University Press

\section{AUTHORS' BIOGRAPHY}

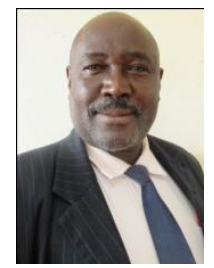

Prof. Njogu Waita holds a $\mathrm{PhD}$ in African Languages and Literatures from the University of Cape Town and a Bachelors and Master's degrees in Literature and a Postgraduate Diploma in Mass Communication and Journalism from the University of Nairobi. He has published widely in areas of African literature (oral and written), gender, African languages and media studies. Prof. Waita has over 30 years university teaching and research experience having taught at the University of Nairobi, Moi University, Egerton University, Laikipia University and Chuka University, all in Kenya. Presently he is teaching literature and media studies at the Department of Humanities in Chuka University.

Citation: Prof. Njogu Waita. "Freudian Psychoanalysis and the African Folktale" International Journal on Studies in English Language and Literature (IJSELL), vol 7, no. 1, 2019, pp. 23-29. doi: http://dx.doi.org/10.20431/2347 -3134.0701003.

Copyright: (C) 2019 Authors. This is an open-access article distributed under the terms of the Creative Commons Attribution License, which permits unrestricted use, distribution, and reproduction in any medium, provided the original author and source are credited. 